\title{
Pancreatic pattern of expression of thyrotropin-releasing hormone during rat embryonic development
}

\author{
A Basmaciogullari, C Cras-Meneur, P Czernichow \\ and R Scharfmann \\ INSERM U457, Hôpital R. Debré, 48 Boulevard Sérurier, 75019 Paris, France \\ (Requests for offprints should be addressed to R Scharfmann; Email: scharfma@infobiogen.fr) \\ (A Basmaciogullari and C Cras-Meneur have contributed equally to this paper)
}

\begin{abstract}
In rodents, the first insulin-producing cells appear in the pancreas at mid-gestation around embryonic day 11 (E11). However, on the basis of various features, such as morphology or hormonal coexpression, it is apparent that these initial insulin-expressing cells are different from those that develop after E15. In the present study, the pancreatic expression of both thyrotropin-releasing hormone (TRH) mRNA and insulin was studied during embryonic and fetal life. We report here that in the rat, while insulin mRNA is detected in the pancreas as early as E12, TRH mRNA cannot be detected before E16. At that stage and later on during fetal and early postnatal life, TRH mRNA
\end{abstract}

is detected in insulin-producing cells, no signal being detected in other endocrine cell types or in exocrine tissue. It was also noted, by means of triple staining performed at E17, that the expression of TRH mRNA was restricted to insulin-expressing cells negative for glucagon, whereas the few insulin-expressing cells present at that stage, which coexpress insulin and glucagon, did not express TRH mRNA. Taken together, these data indicate that TRH is a marker of insulin-expressing cells, which develop after E15.

Journal of Endocrinology (2000) 166, 481-488

\section{Introduction}

In rodents, during embryonic and fetal life, pancreatic development follows a specific pattern that can be divided into three main steps. During the first step, named primary transition and starting around embryonic day 10 (E10), the first insulin-positive cells appear. Their number remains stable during the next 3-4 days, a period called the protodifferentiation state. Finally, the number of insulinpositive cells increases very rapidly from E15, during a period called the secondary transition (Pictet \& Rutter 1972, Herrera et al. 1991). Various features indicate that the insulin-expressing cells found before E15 are different from the ones found after E15 (Pictet \& Rutter 1972, Pang et al. 1994, Miralles et al. 1999).

Thyrotropin-releasing hormone (TRH) is a hypothalamic hormone that has been shown to be expressed in the pancreas (Morley et al. 1977). In this organ, its expression is tightly regulated spatially. Indeed, TRH is specifically found in beta cells in the islets of Langerhans (Martino et al. 1978, Leduque et al. 1987, Scharfmann et al. 1988), where it colocalizes with insulin in the same granules. Its expression is also tightly regulated temporally. Indeed, a large number of studies have demonstrated that the levels of TRH are high in pancreatic beta cells during the neonatal period (Martino et al. 1980, Aratan-Spire et al. 1984) and decrease rapidly, when postnatal development progresses (Martino et al. 1980, Aratan-Spire et al. 1984, Ouafik et al. 1987, Scharfmann et al. 1988). To the best of our knowledge, the prenatal pattern of pancreatic TRH expression remains poorly studied.

The objective of the present study was thus to study the pattern of pancreatic expression of TRH during embryonic and fetal life in insulin-expressing cells. More specifically, our goal was to determine whether insulinexpressing cells developed during the primary and the secondary transition express TRH. Our results demonstrate that while insulin mRNA can be detected in the pancreas as early as E12, TRH expression is not detected before E16. At E16 and later on, TRH mRNA is specifically detected in insulin-expressing cells. These data suggest that TRH mRNA is a marker of mature beta cells that develop during the secondary transition.

\section{Materials and Methods}

Animals and tissue preparation

Non-pregnant and pregnant Wistar rats were purchased from the Janvier breeding center (Le Genet, France). The 
morning of the discovery of the vaginal plug was designated as E0.5. The pregnant rats were killed by cervical dislocation at different stages of gestation. The embryonic pancreases were obtained after microdissection under a Leitz microscope. The tissues were either frozen for RNA extraction or fixed for in situ hybridization or immunohistochemistry.

\section{Cell culture}

INS-1 cells derive from a rat insulinoma (Asfari et al. 1992) and were grown in RPMI 1640 supplemented with penicillin $(100 \mu \mathrm{g} / \mathrm{ml})$, streptomycin $(100 \mu \mathrm{g} / \mathrm{ml}), 10 \%$ fetal calf serum, $1 \mathrm{mM}$ sodium pyruvate, $10 \mathrm{mM}$ Hepes and $50 \mu \mathrm{M} 2$-mercaptoethanol. Cultures were maintained at $37{ }^{\circ} \mathrm{C}$ in a humidified atmosphere of $95 \%$ air and $5 \%$ $\mathrm{CO}_{2}$.

\section{In situ hybridization}

The pancreases were either fixed overnight at $4{ }^{\circ} \mathrm{C}$ in $4 \%$ paraformaldehyde in PBS, briefly rinsed with PBS, cryoprotected overnight at $4{ }^{\circ} \mathrm{C}$ in $30 \%$ sucrose and frozen or fixed in formalin and embedded in paraffin. Sections were cut and collected on Superfrost ${ }^{+}$slides (CML, Nemours, France). Prehybridization was done at $70{ }^{\circ} \mathrm{C}$ in hybridization buffer $(50 \%$ formamide, $5 \times \mathrm{SSC}, 5 \times$ Denhardt's solution, $250 \mu \mathrm{g} / \mathrm{ml}$ yeast RNA, $500 \mu \mathrm{g} / \mathrm{ml}$ herringsperm DNA). RNA probes were labeled with DIG-UTP by in vitro transcription using the DIG-RNA labeling kit (Boehringer Mannheim, Mannheim, Germany). Hybridization was initiated by the addition of fresh hybridization buffer containing probe $(1 \mu \mathrm{g} / \mathrm{ml})$ and then continued overnight at $70{ }^{\circ} \mathrm{C}$. Thereafter, the slides were washed with decreasing concentrations of SSC. Non-specific sites were blocked with 2\% blocking reagent (Boehringer Mannheim) in Tris $(25 \mathrm{mM} \mathrm{pH} \mathrm{7 \cdot 5),} \mathrm{NaCl}(140 \mathrm{mM})$, $\mathrm{KCl}(2 \cdot 7 \mathrm{mM})$ and Tween $20(0 \cdot 1 \%)$ for $30 \mathrm{~min}$ at room temperature. Then slides were incubated overnight at $4{ }^{\circ} \mathrm{C}$ with alkaline phosphatase-conjugated polyclonal sheep anti-DIG antibody (diluted 1:1000; Boehringer Mannheim). The reaction product was visualized by an enzyme-catalyzed color reaction using nitroblue tetrazolium and 5-bromo-4-chloro-3-indolyl-phosphate medium (Boehringer Mannheim). Sections were incubated until the colored reaction product developed at the sites of hybridization. The slides were washed in $\mathrm{H}_{2} \mathrm{O}$, mounted and visualized using a DMRD light microscope (Leica, Heerbrugg, Switzerland). Each experiment was performed at least three times.

The following riboprobes were used: rat proinsulin (Aratan-Spire et al. 1990) and rat proTRH (Segerson et al. 1987).

\section{Immunohistochemistry}

The paraffin sections, first used for in situ hybridization as described above, were next used for immunohisto- chemistry. For that purpose, the sections were first permeabilized using $0 \cdot 1 \%$ Triton X100 in PBS, incubated for $30 \mathrm{~min}$ in Tris-buffered saline (TBS) containing 3\% BSA. Subsequently, the sections were incubated overnight at $4{ }^{\circ} \mathrm{C}$ with the primary antibodies. After washing in TBST (TBS containing $0 \cdot 1 \%$ Tween 20 ), the sections were incubated with the appropriate fluorescent secondary antibodies. Finally, the sections were extensively washed in TBST and mounted with a fluorescence-protecting medium. The sections were examined and photographed with a DMRD microscope (Leica).

The antisera employed in this study were guinea-pig anti-porcine insulin (1:200; Dako S.A., Copenhagen, Denmark) and mouse anti-porcine glucagon (1:2000; Sigma Chemical Co., St Louis, MO, USA). The fluorescent secondary antibodies were fluorescein antiguinea-pig antibodies (1:500; Dako S.A.) and Texas-red anti-mouse antibodies (1:200; Jackson Immunoresearch).

\section{$R N A$ preparation and comparative $P C R$}

Total RNAs were extracted from pancreases and reversetranscribed as described previously (Atouf et al. 1997). For comparative PCR, series of twofold dilutions of the cDNAs were prepared and used as templates in the PCR reactions.

The oligonucleotides used for amplification were as follows: insulin (forward), 5'-CCTAAGTGACCAGCT ACA-3'; insulin (reverse), 5'-GTAGTTCTGCAGTTG GTA-3'; TRH (forward), 5'-ATTCTTGTGGAAAGA CCTCCAGC-3'; TRH (reverse), 5'-GACATCTGAGA ACCAGGAATCCA-3'; TRH receptor 1 (TRHR1; forward), 5'-AGATGTTTCAACAGCACCGTTTC-3'; TRHR1 (reverse), 5'-TCTGTGCTAAAGCGGTCTG ACTC-3'; TRHR2 (forward), 5'-GGTTCTTCCTGGT GGATCTCAAT-3'; TRHR2 (reverse), 5'-GAGCAGT ACCAGTGTGCGGTAAG-3'; cyclophilin (forward), 5'-CAGGTCCTGGCATCTTGTCC-3'; and cyclophilin (reverse), 5'-TTGCTGGTCTTGCCATTCCT$3^{\prime}$.

Typically, 35 cycles of amplification were performed. Amplification parameters included a $30 \mathrm{~s}$ denaturation step at $96{ }^{\circ} \mathrm{C}$, a $30 \mathrm{~s}$ annealing step at $57^{\circ} \mathrm{C}$ and a $30 \mathrm{~s}$ extension step at $73{ }^{\circ} \mathrm{C}$. The products of amplification were separated on a $1.5 \%$ agarose gel and photographed. Each experiment was performed at least three times.

\section{Results}

$R T-P C R$ analysis of the expression of proinsulin and proTRH $m R N A$ in the pancreas in development

As shown in Fig. 1, RNA coding for insulin could be amplified from rat embryonic pancreases as early as E12.5. Some increase in the proinsulin mRNA level was found at 
$\mathbf{A}$

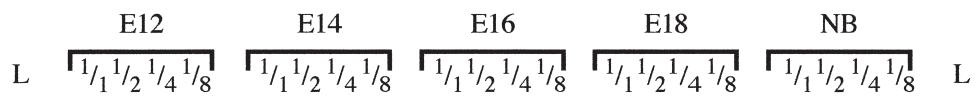

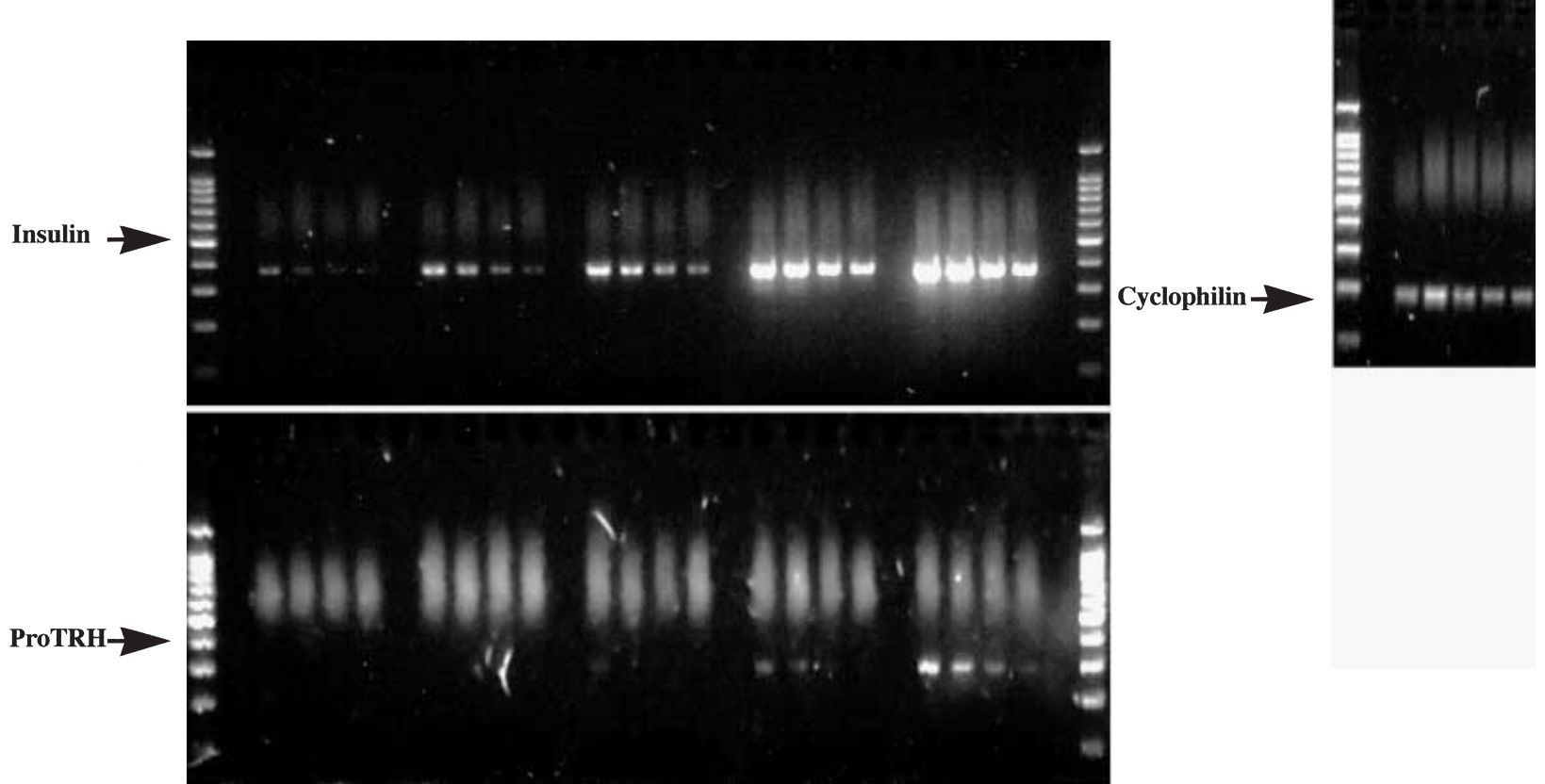

B

L E12E14E16 E18NB

Figure 1 RT-PCR analysis of proinsulin and proTRH mRNA expression in the developing pancreas. (A) Ethidium bromide staining of 1.5\% agarose gels containing proinsulin and proTRH PCR products of reverse-transcribed total RNA from a series of twofold dilutions of cDNAs prepared from rat pancreases at different stages of development. (B) Cyclophilin amplification in non-saturating conditions was used as the control.

E14 when compared with E12. The insulin mRNA level next remained stable between E14 and E16, whereas a sharp increase was seen at E18 and birth.

ProTRH mRNAs were amplified neither at E12.5 nor at E14. A low level of expression was detected at E16, followed by a sharp increase at E18 and birth (Fig. 1).

In situ hybridization for proinsulin and proTRH $m R N A$ in the pancreas in development

In situ hybridization was next performed at different stages of pancreatic development, using proinsulin and proTRH riboprobes. As expected, as shown in Fig. 2, proinsulin mRNA was detected in the pancreas from adult and 2-day-old rats, whereas proTRH mRNA was not detected in the adult pancreas, but was detected in the pancreas of 2-day-old rats. At that stage, proTRH staining was found in the islets of Langerhans. No staining was found when sense probes were used.

The pancreatic patterns of expression of proinsulin and proTRH mRNA were next followed at different prenatal stages on tissue sections. Proinsulin mRNAs could be detected at E20, E18, E16 and E14. On the other hand, while proTRH mRNAs were detected at E20, E18, E16, no expression of proTRH mRNA was detected at
E14 (Fig. 2). Such data correlate with those found by RT-PCR analysis and described above.

Definition of the cell types expressing TRH in the developing pancreas

Pancreatic sections from 4-day-old rats and embryos at E17 were first hybridized with a proTRH riboprobe, followed by double immunohistochemistry using antibodies specific for insulin and glucagon. As shown in Fig. 3 (left-hand panels), in the pancreas of 4-day-old rats, all of the insulin-positive cells expressed TRH, whereas no cells coexpressing TRH-mRNA and glucagon were detected.

At E17, the vast majority of the insulin-expressing cells coexpressed TRH, whereas TRH mRNA was never detected in glucagon-expressing cells (Fig. 3, right-hand panels). At that specific stage, some cells positive for both insulin and glucagon were detected. Such double-positive cells stained negative for TRH (Fig. 3, right-hand panels).

Expression of TRHRs in the developing pancreas

To define whether TRH, which is produced in the pancreas during embryonic life, could act in an autocrine/ 


\section{Proinsulin}

\section{Adult}

D2

E18

E20
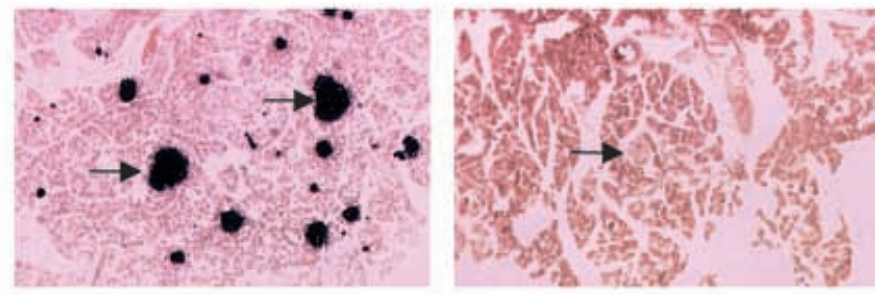

ProTRH
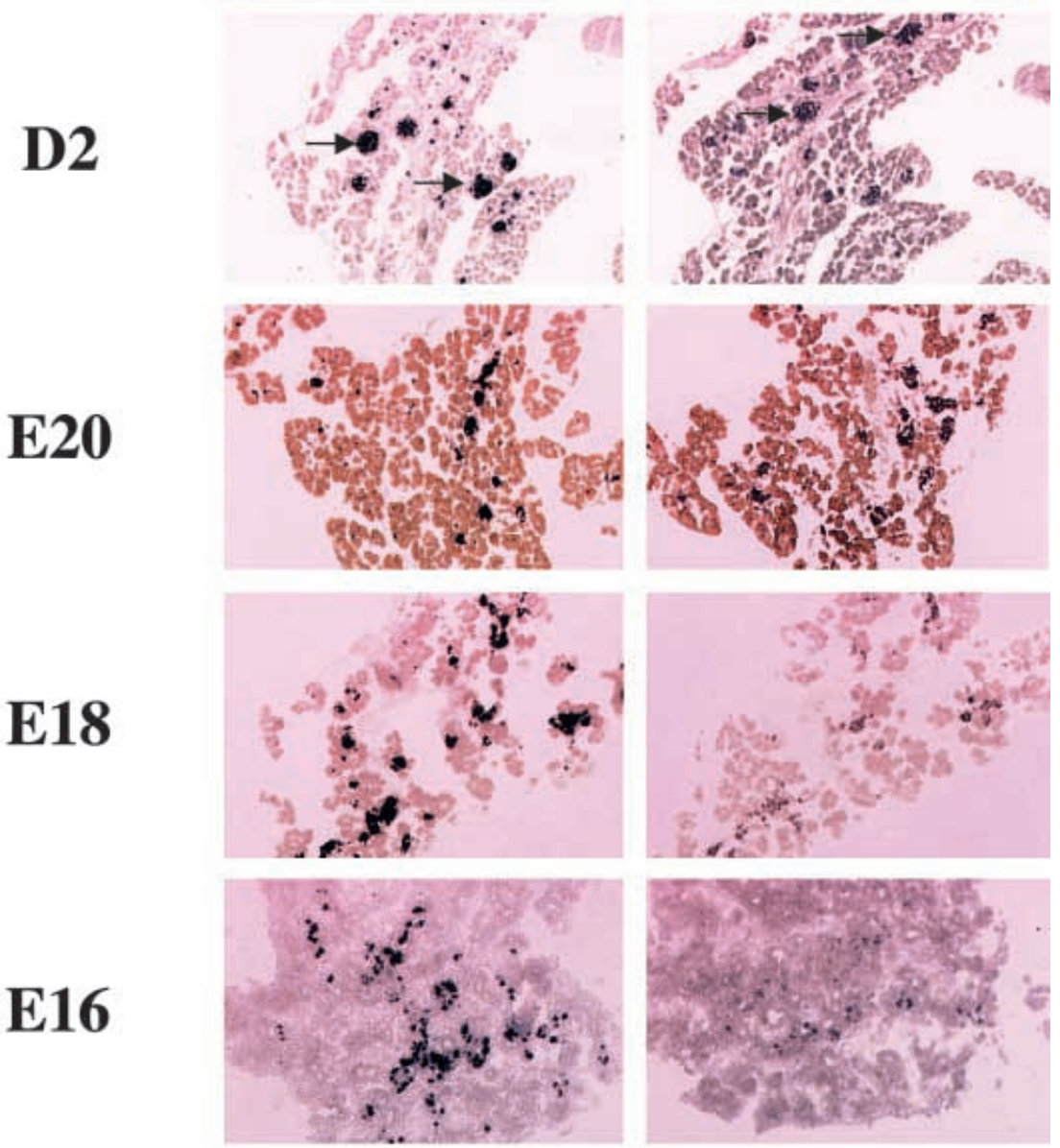

E16
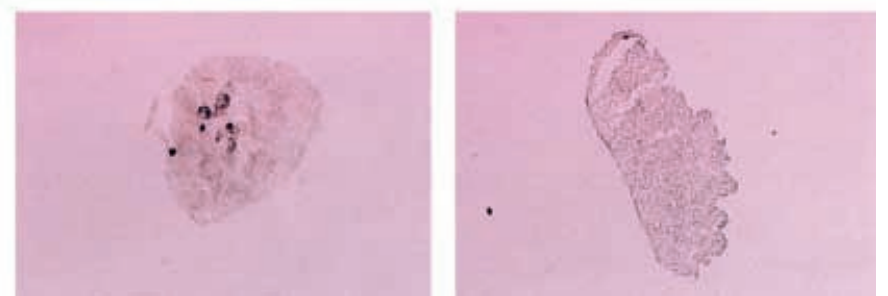

Figure 2 Expression and localization of proinsulin and proTRH mRNA in the rat pancreas at different stages of development. Frozen pancreatic sections from postnatal (adult and 2-day-old) and prenatal (E20, E18, E16 and E14) rats were hybridized with proinsulin or proTRH antisense DIG-labeled riboprobe. Arrows: islets of Langerhans. Original magnification: $\times 100$. 


\section{D4}

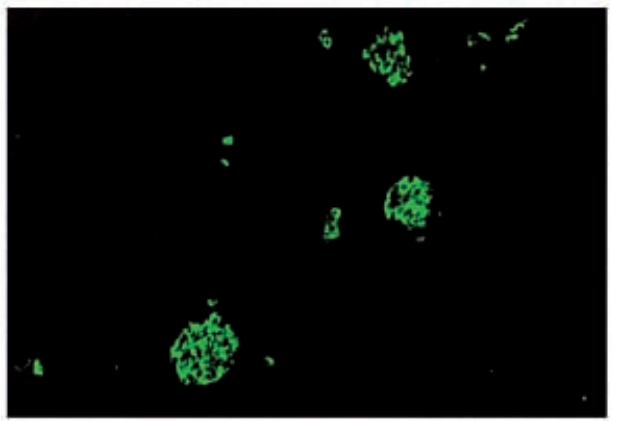

Insulin

\author{
Insulin \\ Glucagon
}
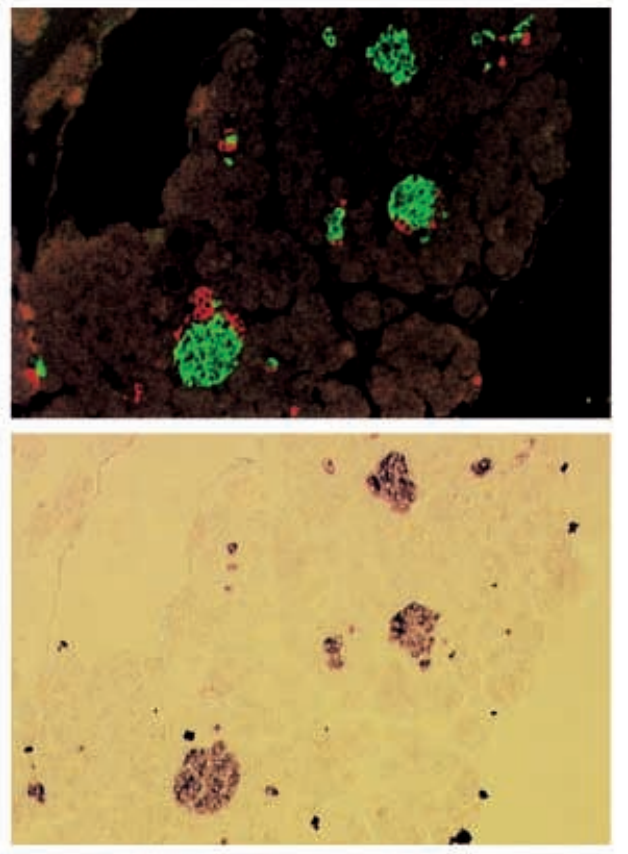

ProTRH

\section{Insulin}

Glucagon ProTRH

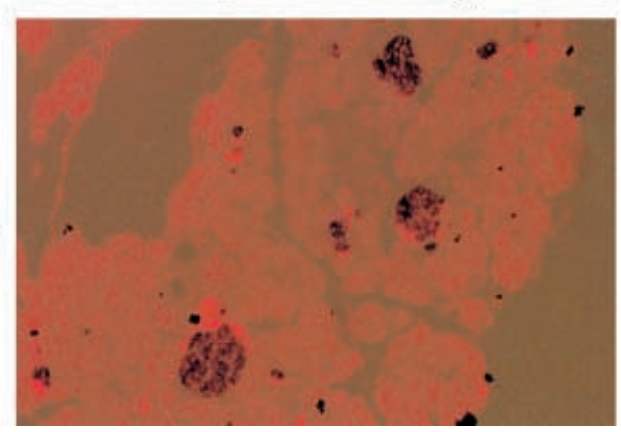

E17
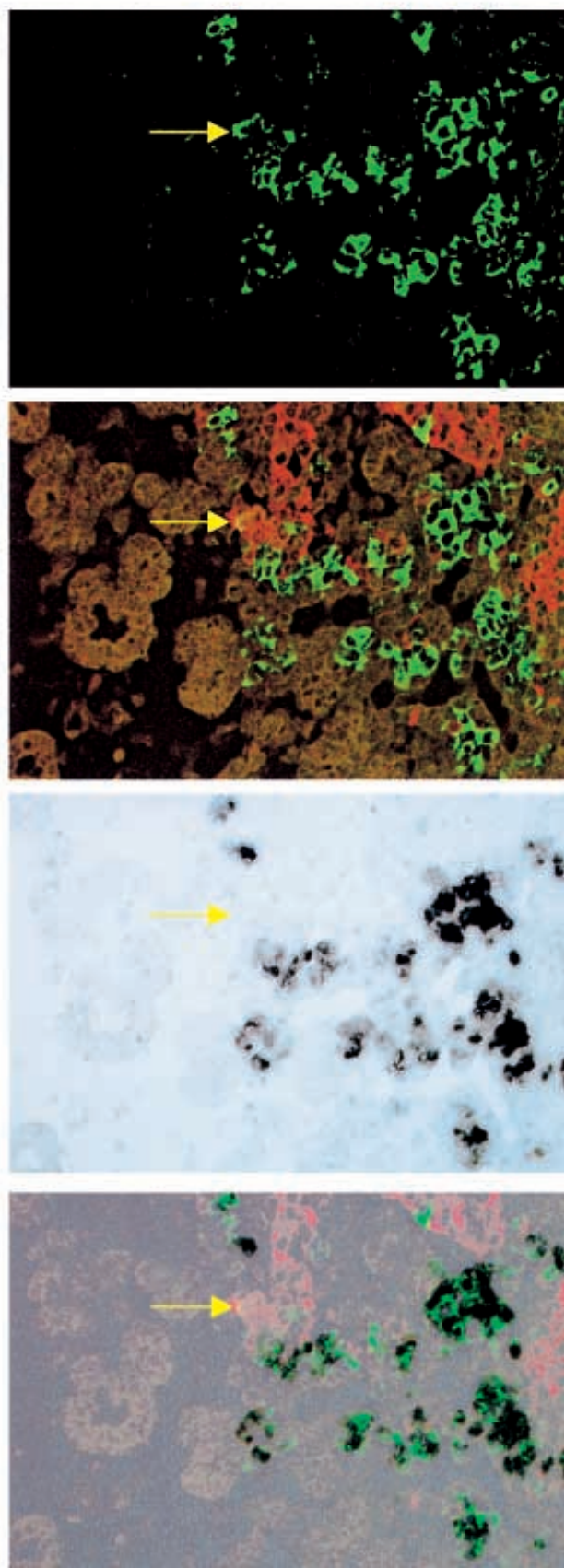

Figure 3 Coexpression of proTRH mRNA and insulin in the developing pancreas. Paraffin-embedded pancreatic sections from postnatal (4-day-old) and prenatal (E17) rats were first hybridized with a proTRH riboprobe (blue staining). The sections were next stained for insulin (green fluorescence) and for glucagon (red fluorescence). Arrows show cells coexpressing insulin and glucagon but negative for Pro-TRH mRNA. Magnification: $\times 100$. 


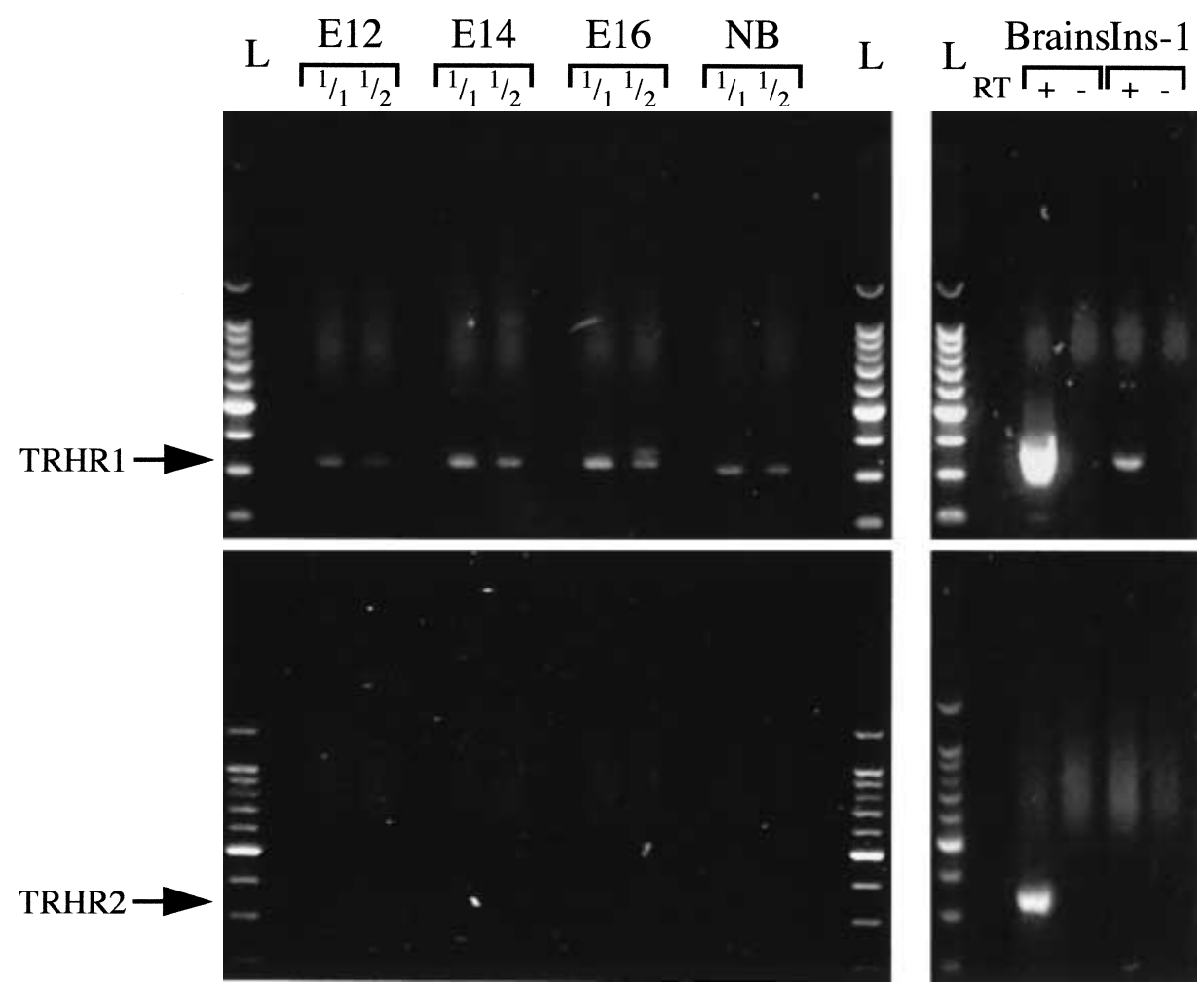

Figure 4 RT-PCR analysis of TRHR1 and TRHR2 mRNA expression in the developing pancreas. The pictures show ethidium bromide staining of $1.5 \%$ agarose gels containing TRHR 1 and TRHR2 products of reverse-transcribed total RNA from cDNAs prepared from rat pancreases at different stages of development, INS-1 cells and brain.

paracrine fashion, we searched for TRHR expression in the pancreas in development. As shown in Fig. 4, mRNA coding for TRHR 1 could be amplified from pancreases at E12, E14, E16 and birth. No major differences were detected at the different stages tested. TRHR1 could also be amplified from the insulin-producing cell line INS-1. On the other hand, while TRHR2 could be amplified from the brain, no amplification of TRHR2 could be detected in the pancreas at the different stages tested or in INS-1 cells (Fig. 4).

\section{Discussion}

In the present study, we demonstrate that TRH is expressed in the rat pancreas during late-embryonic life and early postnatal life. During this period, TRH mRNA is found exclusively in insulin-expressing cells. Moreover, during the same period, TRHR mRNA is expressed in the developing pancreas. On the other hand, before E16, the insulin-positive cells present in the pancreas do not express TRH mRNA.

It has been known for many years that TRH is expressed in the rat pancreas (Morley et al. 1977). Its pattern of expression is tightly controlled in a temporal and cell-type-specific manner. Indeed, in the pancreas, TRH is found at high levels specifically in insulin-expressing cells at around the time of birth, the TRH levels decreasing very rapidly during the first days of postnatal life (Martino et al. 1980, Leduque et al. 1987, Scharfmann et al. 1988). Such data were mainly obtained at the protein level. Our data, obtained at the RNA level, do confirm this specific pattern of expression. However, to the best of our knowledge, very few data have been available concerning the expression of TRH in the pancreas during prenatal life. In fact, there was one report indicating that TRH mRNA was detected in the pancreas of rat at E19 (Dutour et al. 1987). However, in that study, no time points prior to E19 were studied. Moreover, the study (performed by Northern blot analysis) did not permit definition of the pancreatic cell types expressing TRH mRNA at those prenatal stages of development. The present study clearly indicates that before birth $\mathrm{TRH}$ mRNA is specifically found in beta cells.

Our data, obtained by comparative RT-PCR, confirm previous data indicating that, both in the rat and the mouse, insulin levels increase between E12 and E14 (a period called the primary transition). These levels remain 
quite stable between E14 and E16 and increase very rapidly after E16, during a period called the secondary transition (Pictet \& Rutter 1972, Herrera et al. 1991). The present data indicate that, while the insulin-expressing cells that develop during the secondary transition express $\mathrm{TRH}$, the ones that develop during the primary transition stain negative for TRH. In fact, previous data from the literature have indicated that, on the basis of different criteria, insulin-expressing cells present in the pancreas during early embryonic life are different from the ones present later during prenatal life. Prior to E15, insulinexpressing cells contain neither granules resembling those found in mature beta cells (Pictet et al. 1972) nor Rab3A and SNAP-25 (Miralles et al. 1999), two molecules important for the control of insulin secretion (Sadoul et al. 1995, Regazzi et al. 1996). Moreover, prior to E15, insulin-expressing cells stain negative for the glucose transporter Glut2 (Pang et al. 1994). Finally, such embryonic insulin-expressing cells coexpress glucagon (Alpert et al. 1988, Pang et al. 1994, Jackerott et al. 1996, Miralles et al. 1998, 1999). Our results, described in the present study, indicate that such cells, which coexpress insulin and glucagon, stain negative for TRH, whereas the insulinexpressing cells present later, after E16, express TRH. Thus TRH does represent a new marker for beta cells, which developed during the secondary transition.

In endocrine organs, such as the pituitary, two populations of thyrotrope cells develop. While the first population appears at E12 in the rostral tip of the developing gland, the second one develops 3 days later in the caudiomedial region of the gland. In this organ, it has been proposed that these two cell populations arise independently (Lin et al. 1994). In the pancreas, the relationship between the insulin-expressing cells that develop during the primary and secondary transitions remains unknown. It had been proposed, on the basis of indirect evidence, that the insulin-expressing cells that develop during the primary transition could represent precursor cells for the insulin-expressing cells, which develop later on (Alpert et al. 1988). However, the fact that a large number of markers such as, for example, Glut2 (Pang et al. 1994), Pdx-1 (Ahlgren et al. 1996) or proTRH (the present study) are absent from insulin-containing cells which develop early during development could indicate that these two cell populations develop independently.

Recently, it was shown that mice with a targeted disruption of the TRH gene exhibited hyperglycemia and impaired insulin secretion in response to glucose (Yamada et al. 1997). One hypothesis for this was that TRH produced in the pancreas could act in a paracrine/ autocrine fashion to regulate pancreatic development. In that case, TRHR would have to be expressed in the developing pancreas. To the best of our knowledge, no information has been available concerning the expression of TRHR in the developing pancreas. In rodents, two different TRHRs have been cloned. TRHR1 has been found to be expressed in the anterior pituitary (Straub et al. 1990, de la Pena et al. 1992) and in the hypothalamus, testes and thymus (Montagne et al. 1999). More recently, a cDNA encoding a novel subtype of TRHR has been cloned. This type of receptor was found to be expressed specifically in the brain (Cao et al. 1998, Itadani et al. 1998). We demonstrate in the present study that mRNA coding for TRHR1, but not TRHR2, is detected in the embryonic developing pancreas. Taken together, these data strongly suggest that TRH is a marker of insulinexpressing cells that develop after E15. It could play a role, in an autocrine/paracrine fashion, in the development of the pancreas.

\section{Acknowledgements}

This work was supported by grants from the Juvenile Diabetes Foundation International.

\section{References}

Ahlgren U, Jonsson J \& Edlund H 1996 The morphogenesis of the pancreatic mesenchyme is uncoupled from that of the pancreatic epithelium in IPF1/PDX1-deficient mice. Development 122 1409-1416.

Alpert S, Hanahan D \& Teitelman G 1988 Hybrid insulin genes reveal a developmental lineage for pancreatic endocrine cells and imply a relationship with neurons. Cell 53 295-308.

Aratan-Spire S, Wolf B, Portha B, Bailbe D \& Czernichow P 1984 Streptozotocin treatment at birth induces a parallel depletion of thyrotropin-releasing hormone and insulin in the rat pancreas during development. Endocrinology 114 2369-2373.

Aratan-Spire S, Scharfmann R, Lechan RM \& Tashjian AH Jr 1990 proTRH gene expression by fetal pancreatic islets in culture. Biochemical and Biophysical Research Communications 168 952-958.

Asfari M, Janjic D, Meda P, Li G, Halban P \& Wolheim K 1992 Establishement of 2-mercaptoethanol-dependent differentiated insulin secreting cell lines. Endocrinology 130 167-178.

Atouf F, Czernichow P \& Scharfmann R 1997 Expression of neuronal traits in pancreatic beta cells. Implication of neuron-restrictive silencing factor/repressor element silencing transcription factor, a neuron-restrictive silencer. Journal of Biological Chemistry 272 1929-1934.

Cao J, O’Donnell D, Vu H, Payza K, Pou C, Godbout C, Jakob A, Pelletier M, Lembo P, Ahmad S \& Walker P 1998 Cloning and characterization of a cDNA encoding a novel subtype of rat thyrotropin-releasing hormone receptor. Journal of Biological Chemistry 273 32281-32287.

Dutour A, Giraud P, Kowalski C, Ouafik L, Salers P, Strbak V \& Oliver C 1987 Ontogenesis of TRH mRNA in the rat pancreas. Biochemical and Biophysical Research Communications 146 354-360.

Herrera P, Huarte J, Sanvito F, Meda P, Orci L \& Vassali J 1991 Embryogenesis of the murine pancreas; early expression of pancreatic polypeptide gene. Development 113 1257-1265.

Itadani H, Nakamura T, Itoh J, Iwaasa H, Kanatani A, Borkowski J, Ihara M \& Ohta M 1998 Cloning and characterization of a new subtype of thyrotropin-releasing hormone receptors. Biochemical and Biophysical Research Communications 250 68-71.

Jackerott M, Oster A \& Larsson L 1996 PYY in developing murine islet cells: comparisons to development of islet hormones, NPY, and BrdU incorporation. Journal of Histochemistry and Cytochemistry 44 809-817. 
Leduque P, Aratan-Spire S, Wolf B, Dubois PM \& Czernichow P 1987 Localization of thyrotropin-releasing hormone- and insulinimmunoreactivity in the pancreas of neonatal rats after injection of streptozotocin at birth. Cell and Tissue Research 248 89-94.

Lin SC, Li S, Drolet DW \& Rosenfeld MG 1994 Pituitary ontogeny of the Snell dwarf mouse reveals Pit-1-independent and Pit-1dependent origins of the thyrotrope. Development 120 515-522.

Martino E, Lernmark A, Seo H, Steiner DF \& Refetoff S 1978 High concentration of thyrotropin-releasing hormone in pancreatic islets. PNAS 75 4265-4267.

Martino E, Seo H, Lernmark A \& Refetoff S 1980 Ontogenetic patterns of thyrotropin-releasing hormone-like material in rat hypothalamus, pancreas and retina: selective effect of light deprivation. PNAS 77 4345-4348.

Miralles F, Czernichow P \& Scharfmann R 1998 Follistatin regulates the relative proportions of endocrine versus exocrine tissue during pancreatic development. Development 125 1017-1024.

Miralles F, Serup P, Cluzeaud F, Vandewalle A, Czernichow P \& Scharfmann R 1999 Characterization of beta cells developed in vitro from rat embryonic pancreatic epithelium. Developmental Dynamics 214 116-126.

Montagne JJ, Ladram A, Nicolas P \& Bulant M 1999 Cloning of thyrotropin-releasing hormone precursor and receptor in rat thymus, adrenal gland, and testis. Endocrinology 140 1054-1059.

Morley JE, Garvin TJ, Pekary AE \& Hershman JM 1977 Thyrotropinreleasing hormone in the gastrointestinal tract. Biochemical and Biophysical Research Communications 79 314-318.

Ouafik L, Giraud P, Salers P, Dutour A, Castanas E, Boudouresque F \& Oliver C 1987 Evidence for high peptide alpha-amidating activity in the pancrease from neonatal rats. PNAS 84 261-264.

Pang K, Mukonoweshuro C \& Wong G 1994 Beta cells arise from glucose transporter type 2 (Glut2)-expressing epithelial cells of the developing pancreas. PNAS 91 9559-9563.

de la Pena P, Delgado LM, del Camino D \& Barros F 1992 Cloning and expression of the thyrotropin-releasing hormone receptor from GH3 rat anterior pituitary cells. Biochemical Journal 284 891-899.
Pictet R \& Rutter W (eds) 1972 Development of the embryonic pancreas. In Handbook of Physiology. Baltimore: Williams \& Wilkins.

Pictet RL, Clark WR, Williams RH \& Rutter WJ 1972 An ultrastructural analysis of the developing embryonic pancreas. Developmental Biology 29 436-467.

Regazzi R, Ravazzola M, Lezzi M, Lang J, Zahraoui A, Andereggen E, Morel P, Takai Y \& Wollheim C 1996 Expression, localization and functional role of small GTPases of the Rab3 family in insulinsecreting cells. Journal of Cell Science 109 2265-2273.

Sadoul K, Lang J, Montecucco C, Weller U, Regazzi R, Catsicas S, Wollheim C \& Halban P 1995 SNAP-25 is expressed in islets of Langerhans and is involved in insulin secretion. Journal of Cellular Biology 128 1019-1028.

Scharfmann R, Leduque P, Aratan-Spire S, Dubois P, Basmaciogullari A \& Czernichow P 1988 Persistence of peptidylglycine alphaamidating monooxygenase activity and elevated thyrotropinreleasing hormone concentrations in fetal rat islets in culture. Endocrinology 123 1329-1334.

Segerson TP, Hoefler H, Childers H, Wolfe HJ, Wu P, Jackson IM \& Lechan RM 1987 Localization of thyrotropin-releasing hormone prohormone messenger ribonucleic acid in rat brain in situ hybridization. Endocrinology 121 98-107.

Straub RE, Frech GC, Joho RH \& Gershengorn MC 1990 Expression cloning of a cDNA encoding the mouse pituitary thyrotropin-releasing hormone receptor. PNAS 87 9514-9518.

Yamada M, Saga Y, Shibusawa N, Hirato J, Murakami M, Iwasaki T, Hashimoto K, Satoh T, Wakabayashi K, Taketo MM \& Mori M 1997 Tertiary hypothyroidism and hyperglycemia in mice with targeted disruption of the thyrotropin-releasing hormone gene. PNAS 94 10862-10867.

Received 2 February 2000

Accepted 18 April 2000 